\title{
Histoplasmosis en caninos y felinos: signos clínicos, métodos de diagnóstico y tratamiento
}

\author{
Canine and feline histoplasmosis: clinical signs, \\ diagnostic methods and treatment
}

\author{
Martínez Cepeda $\mathrm{GE}^{1^{*}}$, Revelo Ruales AP ${ }^{2}$ \\ ${ }^{1}$ Cátedra de Patología, Carrera de Ingeniería Agropecuaria, Extensión Chone, Universidad Laica \\ "Eloy Alfaro" de Manabí; Agencia Ecuatoriana de Aseguramiento de la Calidad del Agro. \\ ${ }^{2}$ Agencia Ecuatoriana de Aseguramiento de la Calidad del Agro, Ecuador. \\ *Correo electrónico del autor: galomartinez88@gmail.com
}

\begin{abstract}
Resumen: La histoplasmosis es una enfermedad zoonótica, causada por el hongo dimórfico Histoplasma capsulatum, endémica en zonas tropicales, subtropicales y templadas de América y África. Suelos con abundante materia orgánica, excremento de aves y guano de murciélagos constituyen el nicho ecológico de este microorganismo. Esta micosis puede afectar a gran variedad de mamíferos. En esta revisión bibliográfica se aborda el tema de la histoplasmosis canina y felina, haciendo referencia, principalmente, a los métodos diagnósticos directos e indirectos empleados para su identificación. Además, se describen las manifestaciones clínicas características de cada fase de la enfermedad y su tratamiento y se presenta un algoritmo de diagnóstico.
\end{abstract}

Palabras clave: Histoplasma spp.; zoonosis; signología; diagnóstico; tratamiento

\begin{abstract}
Histoplasmosis is a zoonotic disease affecting a wide variety of animals caused by Histoplasma capsulatum, a dimorphic fungus endemic in tropical, subtropical and temperate regions of America and Africa. Soil with abundant organic material, bird droppings and bat guano, constitutes the ecological niche of this microorganism. In this literature review the issue of canine and feline histoplasmosis is addressed, referring mainly to direct and indirect diagnostic methods employed for identification. Clinical manifestations characteristic of each stage of the disease and their treatments are described; also, a diagnostic algorithm is presented.
\end{abstract}

Keywords: Histoplasma spp.; zoonosis; signology; diagnosis; treatment 


\section{Introducción}

\section{Historia de la enfermedad}

La histoplasmosis o enfermedad de Darling fue descripta en 1905 por el médico patólogo estadounidense Samuel Taylor Darling (1872-1925), cuando trabajaba en el Hospital Ancón del canal de Panamá, al realizar una autopsia de un paciente de la isla Martinica que había fallecido por una enfermedad parecida a la tuberculosis. En los cortes histológicos encontró corpúsculos intracelulares en los histiocitos. En una primera instancia pensó que había descubierto un nuevo protozoario y lo llamó Histoplasma capsulatum porque aparentaba tener cápsula. En Brasil, en 1912, se determinó que el agente no tiene cápsula ni es protozoo, aunque se mantuvo el nombre (Kauffman, 2007; Sánchez-Alemán, 2009).

\section{Agente etiológico}

Histoplasma capsulatum, un hongo dimórfico, es el agente etiológico de la histoplasmosis. La micosis sistémica es endémica en zonas tropicales, subtropicales y templadas de América y África. Actualmente, la micosis es considerada cosmopolita. El hongo crece en suelos con abundante materia orgánica, excremento de aves (pollos, gansos, pavos y algunas aves migratorias, entre otras) y guano de murciélagos en ambientes cerrados, tales como minas, cuevas, cavernas, túneles, criptas de iglesias y casas abandonadas, o en espacios abiertos, entre ellos parques y paseos públicos. La materia orgánica en descomposición, en condiciones de humedad y temperatura adecuadas, constituye el nicho ecológico para que desarrolle la fase micelial del hongo y se formen los microconidios que constituyen la principal forma infectante de Histoplasma (Castañón-Olivares, 2014; López, 2006).

Existen tres variedades taxonómicas de $\mathrm{H}$. capsulatum: Hc var. capsulatum, var. duboisii y var. farciminosum. La primera variedad es endémica de
América y algunas zonas de África, Asia y Europa. La segunda únicamente se aisló en África y la tercera se identificó en Europa, África y Asia y es patógena para caballos y mulas. Las variedades capsulatum y duboisii se diferencian en su fase levaduriforme en tejidos animales. Hc var. duboisii es ovoide, más grande y de paredes más gruesas que la variedad capsulatum, aunque en su fase micelial las dos variedades no muestran diferencias marcadas (Kwon-Chung \& Bennett, 1992; Rippon, 1988).

En estudios filogenéticos realizados en 137 aislamientos de $H$. capsulatum pertenecientes a las tres variedades descritas, aislados de pacientes humanos provenientes de 25 países, se utilizaron las secuencias de ADN correspondientes a cuatro genes independientes que codifican a proteínas: arf (factor de ribosilación de ADP), anti-H (precursor del antígeno $H$ ), ole (ácido graso desaturasa delta-9) y tub1 ( $\alpha$-tubulina) (Kasuga et al., 1999). Como resultado se encontraron ocho clados notoriamente separados e identificados: clado I de América del Norte (Hc var. capsulatum), clado II de América del Norte (Hc var. capsulatum), clado III de Sudamérica (Hc var. capsulatum Grupo A), clado IV de Sudamérica ( $H c$ var. capsulatum Grupo B), clado V de Australia, clado VI de Holanda (origen indonésico), clado VII euroasiático y clado VIII de África. De los ocho clados descritos, siete representan especies filogenéticas, con excepción del clado euroasiático (Kasuga et al., 2003).

En esta clasificación $\mathrm{Hc}$ var. capsulatum fue encontrado en los ocho clados. El clado africano incluyó a todos los aislamientos de Hc var. duboisii, así como a miembros de las otras dos variedades, mientras que todos los miembros de la var. farciminosum quedaron distribuidos en tres especies filogenéticas, las que al momento de cultivar su forma saprófita forman dos tipos de colonias: el tipo A (albino o blanco) y el tipo B (marrón o pardo) (Kasuga et al., 1999, 2003).

\section{Clasificación taxonómica}

* División: Ascomycota

$>$ Clase: Euascomycetes

- Orden: Onygenales

- Familia: Onygenaceae y/o Ajellomycetaceae

- Género: Emmonsiella (Ajellomyces) - estado teleomorfo

Histoplasma - estado anamorfo

> Especie: capsulata (estado teleomorfo), capsulatum, (estado anamorfo) (Peterson et al., 1998; Vite-Garín et al., 2014) 
Hc var. capsulatum es un hongo termodimórfico que a temperaturas inferiores a $35^{\circ} \mathrm{C}$ crece como un hongo micelial entre los 10 y 14 días. Macroscópicamente, en la fase micelial presenta un micelio blanco y algodonoso. Microscópicamente, los microconidios se presentan sésiles (o en hifas cortas no diferenciadas), lisos, esféricos, piriformes o en forma de clava, sin septos, de pared fina. Pueden medir 1-4 x 2-6 $\mu \mathrm{m}$. Los macroconidios se observan en conidióforos cortos, son en general esféricos (8-14 $\mu \mathrm{m}$ de diámetro), de paredes gruesas, sin septos, de aspecto tuberculado, bien apreciables al microscopio óptico (Fernández-Andreu et al., 2011).

Las levaduras del hongo se desarrollan a $37{ }^{\circ} \mathrm{C}$; para evidenciarlas se las debe sembrar en medios de cultivo enriquecidos o realizar infecciones experimentales en animales de laboratorio para luego observarlas en los tejidos del animal con alguna técnica histológica. Las levaduras observadas en los cortes histológicos son de forma esférica u ovalada, de 2-3 x 3-4 $\mu \mathrm{m}$, poseen paredes finas y pueden o no presentar gemación. El hongo puede presentar color grisáceo o castaño claro cuando se lo siembra en medios enriquecidos (Fernández-Andreu et al., 2011).

Los componentes principales de la pared del hongo son: $\alpha-1,3$ glucano, $\beta-1,3$ glucano y quitina. Una de las características destacables de $H$. capsulatum es la cantidad de quitina, que es superior a la encontrada en otros hongos dimórficos (Hearn et al., 1997).

Los factores de virulencia más destacables son los altos niveles de $\alpha-1,3$ glucano en la fase levaduriforme y de galactomanano, el cual es considerado el más importante polisacárido antigénico (Hearn et al., 1997).

Woods et al. (2003) clasificaron los determinantes de patogenicidad y sus causas potenciales como se describen a continuación:

a) la formación de numerosos microconidios en su fase micelial asegura una adecuada forma de diseminación y contagio para el animal susceptible

b) el dimorfismo térmico y la resistencia frente al fagolisosoma de los macrófagos ayuda a la diseminación y enfermedad pulmonar

c) la habilidad de causar infección persistente, debido a su capacidad de modulación del $\mathrm{pH}$ que permite proteger al hongo frente a enzimas degradativas lisosomales (hidrolasas ácidas)

d) la producción de catalasas y oxidasas le permite defenderse frente al $\mathrm{O} 2$ reactivo del hospedero

e) la producción de sideróforos, proteínas fijadoras de calcio y capacidad de reducir los iones férricos
$\left(\mathrm{Fe}^{3+}\right)$ le permite la supervivencia en un ambiente pobre de nutrientes

f) el gen ura5 que otorga al hongo la capacidad de biosintetizar pirimidina y ácidos nucleicos en un microambiente con limitación de nutrientes

\section{Signos clínicos en caninos y felinos}

La histoplasmosis es una infección sistémica que suele iniciarse en los pulmones o en el tracto gastrointestinal, diseminándose posteriormente a linfonódulos, hígado, bazo, médula ósea, ojos y demás órganos (Morgan et al., 2004).

Histoplasma spp. es un patógeno intracelular que se ubica en vesículas fagocíticas en el citoplasma de los macrófagos del hospedero. Se mencionan cinco formas clínicas: asintomática, pulmonar aguda benigna, pulmonar crónica, diseminada aguda y diseminada crónica (Kauffman 2007; Wheat 2006).

La enfermedad se desarrolla en una gran variedad de mamíferos. Los gatos son más susceptibles que los perros. Los perros menores de cuatro años son los más vulnerables a la enfermedad. Los perros de las razas pointer, Brittany spaniel y weimaraner se infectan más comúnmente. No existe predilección por sexo, tanto en perros como en gatos (Morgan et al., 2004).

La principal vía de infección suele ser la inhalación de conidios infectivos procedentes del ambiente, tanto en gatos como en perros y seres humanos. Tras la inhalación, los conidios pasan de la fase micelial a la fase de levadura y éstas son fagocitadas por células del sistema mononuclear fagocitario, donde se multiplican como levaduras intracelulares. La diseminación hematógena y linfática dan lugar a la enfermedad multisistémica (Ettinger \& Feldman 2004; Morgan et al., 2004).

Aunque la diseminación del agente puede afectar a cualquier sistema, los órganos más afectados en perros son: pulmones, tracto gastrointestinal, linfonódulos, hígado, bazo, médula ósea, ojos y glándulas adrenales. En los gatos los órganos más afectados son: pulmones, hígado, linfonódulos, ojos y médula ósea (Morgan et al., 2004).

El tipo de enfermedad desarrollada, tanto en perros como en gatos, va a depender de la respuesta inmunitaria del hospedero. En los perros, el periodo de incubación es de 16 días, aproximadamente. Cuando el sistema inmunitario es competente las infecciones son subclínicas, mientras que la falta de respuesta conduce a la enfermedad diseminada. Los brotes comúnmente suelen asociarse con exposiciones en zonas muy contaminadas por la fase micelial, como gallineros, cavernas con poblaciones de murciélagos y sitios de nidación de estorninos (Ettinger \& Feldman, 2004). 


\section{Fases de la enfermedad}

La histoplasmosis se desarrolla en dos fases; la fase primaria, caracterizada por causar una reacción pulmonar o cutánea, y la fase progresiva, que es la diseminación del agente causal en todo el organismo.

\section{Manifestaciones clínicas en caninos}

La infección se produce por la inhalación de conidios o filamentos, desencadenando cualquiera de los tipos de presentación de la enfermedad. En el pulmón el hongo pasa a su forma levaduriforme; el sistema inmunitario del individuo reacciona por medio de las integrinas CD11 y CD18 que se encuentran en la superficie de neutrófilos y macrófagos. Gracias a sus mecanismos de defensa, el hongo resiste la acción lisosomal y sobrevive dentro del macrófago, permitiendo su diseminación y afectando principalmente médula ósea, linfonódulos, hígado y bazo.

Las manifestaciones gastrointestinales más habituales en el hospedero, inicialmente, son diarreas de intestino grueso y tenesmo con eliminación de moco y sangre fresca. Con la progresión de la enfermedad aparece la diarrea de intestino delgado de forma voluminosa y asociada con malabsorción y/o enteropatía con pérdida de proteínas. La producción de mediadores inflamatorios produce manifestaciones inespecíficas, tales como anorexia, fiebre, grave pérdida de peso y depresión (Morgan et al., 2004). La tos en los perros no es frecuente. En caso de estar presente se debería al estrechamiento de las vías respiratorias a causa de las múltiples linfadenopatías (Bromel \& Sykes, 2005; Nishifuji et al., 2005; Schumacher et al., 2013).

En la mitad de los casos descriptos se presentan sonidos pulmonares patológicos con o sin tos, taquipnea o disnea. En algunos casos se pueden detectar esplenomegalia, hepatomegalia y linfadenopatía. Los signos menos frecuentes son cojeras (debidas a osteomielits o poliartritis), coriorretinitis, enfermedad del sistema nervioso central, lesiones cutáneas, ulceración oral e insuficiencia adrenal. La neuritis óptica y el desprendimiento de la retina también pueden presentarse en pacientes con enfermedad diseminada (Fernández-Andreu et al., 2011; Castañón-Olivares 2014).

En un estudio retrospectivo, Mitchell y Stark (1980) encontraron que en 18 de 24 casos (75\%), un solo informe tenía historia y/o signos clínicos relacionados con el tracto gastrointestinal. Aunque poco común, como en los gatos, la histoplasmosis podría causar un síndrome gastrointestinal sin signos respiratorios detectables (Peterson, 2003).

Curiosamente, la histoplasmosis diagnosticada en un perro en Japón estaba caracterizada por múltiples lesiones granulomatosas o úlceras cutáneas o gingivales, sin compromiso pulmonar ni gastrointestinal. Las lesiones eran similares a la histoplasmosis equina reportada en Japón (Kagawa et al., 1998). Hc var. farciminosum fue el agente causal en el perro de Japón, mientras que en América del Norte, los aislados pertenecian a $\mathrm{Hc}$ var. capsulatum (Kagawa et al., 1998).

Los hallazgos hematológicos incluyen anemia normocítica, normocrómica y no regenerativa; es la anomalía hematológica más frecuente, producto de la inflamación crónica, la pérdida de sangre debida a gastro y enterorragias o el compromiso de la médula ósea (Morgan et al., 2004). Es raro observar levaduras en monocitos, neutrófilos o eosinófilos. Por el contrario, es habitual la trombocitopenia producida por un aumento de la utilización de las plaquetas o de su destrucción. La hipoalbuminemia es la alteración más consistente observada en análisis químico del suero. El aumento de las enzimas hepáticas alaninaaminotransferasa (ALT), aspartatoaminotransferasa (AST) y fosfatasa alcalina (FA) y de la bilirrubina total (BT), indica el compromiso hepático (Gómez et al., 2005; Gómez \& Guida 2010).

En estudios radiográficos se observaron patrones intersticiales difusos o lineales que podían fusionarse en un patrón intersticial nodular. En muy pocos casos se evidenció infiltrado alveolar. Una de las manifestaciones más comunes en perros es la linfadenopatía hiliar. Los linfonódulos con focos de calcificación suelen ser indicativos de enfermedad inactiva. Las lesiones óseas son muy raras y se hallan en el esqueleto apendicular distal, en especial en carpos y tarsos (Ettinger \& Feldman, 2003).

La observación de signos neurológicos en casos de histoplasmosis es inusual, por lo que un examen de líquido cefalorraquídeo no forma parte de las pruebas diagnósticas para identificar esta micosis (Meadows et al 1992). Sin embargo, Reginato et al. (2014) documentaron el primer caso en Italia de histoplasmosis canina con lesión confinada al sistema nervioso central. El animal presentó paraparesia aguda y progresiva y dolor dorso-lumbar. La resonancia magnética permitió observar una masa epidural que fue extraída mediante laminectomía. Durante el estudio histopatológico se encontraron macrófagos con estructuras intracitoplasmáticas semejantes a levaduras. Mediante técnicas especiales de tinción y de PCR se identificó a $H$. capsulatum como el agente causal.

\section{Manifestaciones clínicas en felinos}

La histoplasmosis afecta más frecuentemente a gatos que a perros. Puede iniciarse tanto en los pulmones como en el tracto gastrointestinal, diseminándose posteriormente a los linfonódulos y de ahí hacia otros órganos. Los gatos jóvenes presentan un mayor 
riesgo, aunque la histoplasmosis es una enfermedad que puede afectar a animales de cualquier edad y sexo. El desarrollo de la enfermedad depende del estado inmunitario del animal, puesto que un sistema inmunológico competente evitará el desarrollo de una enfermedad diseminada.

Los signos comunes y habituales son anorexia, fiebre, palidez de mucosas o pérdida de peso. El $50 \%$ de los animales afectados presenta signos respiratorios, tales como disnea, taquipnea y ruidos pulmonares anómalos, aunque la tos no es frecuente. El $35 \%$ de los felinos presenta hepatomegalia, esplenomegalia o linfadenopatía. En casos de infecciones oculares se han comprobado granulomas de párpado, proliferación pigmentada de la retina, edema retiniano, coriorretinitis granulomatosa, uveítis anterior, panoftalmitis y neuritis óptica. Son poco frecuentes los desprendimientos de retina y el glaucoma secundario (Ettinger \& Feldman, 2004).

Las lesiones óseas se manifiestan por medio de alteraciones locomotoras evidenciadas por cojeras y por la inflamación de los tejidos blandos (Carme et al., 1993; Gugnani \& Muotoe-Okafor, 1997). Las lesiones cutáneas son poco frecuentes y consisten en nódulos que llegan a ulcerarse y drenar o cubrirse con costras. Los signos digestivos, otros que la anorexia, son poco frecuentes. Son muy raras las úlceras orales y linguales; en ocasiones se puede presentar ictericia cuando hay compromiso hepático. Por lo general, la forma de presentación de la enfermedad es multisistémica, produciendo en los órganos afectados lesiones granulomatosas. Las presentaciones clínicas atípicas incluyen las formas ósea diseminada e intestinal (intestinos delgado y grueso) sin compromiso pulmonar concomitante. En esta última se pueden observar caquexia, fiebre, diarrea acuosa con hematoquecia y vómitos (Schaer, 2006).

El periodo de incubación se extiende durante 8-11 semanas. En un estudio, sólo el $36 \%$ de los casos presentó signos clínicos antes de las 4 semanas. Los signos clínicos, en general, eran inespecíficos, aun en la forma diseminada grave, en el $95 \%$ de los 54 casos felinos que fueron diagnosticados en la necropsia (Abidon-Aidé, 2009; Aulakh et al., 2012).

Una revisión de 96 gatos con histoplasmosis reveló la siguiente distribución de los signos clínicos: debilidad, letargo, adelgazamiento y fiebre (67\%), signos respiratorios incluyendo disnea, taquipnea o tos $(39 \%)$, signos oculares $(24 \%)$ y cojera o hinchazón de uno o más miembros por compromiso óseo (18\%). En este estudio también se comprobaron afecciones oculares en el $24 \%$ de los gatos, incluyendo coroiditis, coriorretinitis, neuritis óptica, uveítis anterior, desprendimiento de retina, panoftalmitis y glaucoma (Davies et al., 1996).

En otro informe los pacientes presentaron pér- dida de peso, anorexia, signos respiratorios (disnea, taquipnea, tos, estornudos, dificultades para respirar), inflamación cutánea, ulceración, cojera, náuseas y vómitos (Aulakh et al., 2012). Aunque se ha descrito ocasionalmente en la literatura, los gatos con histoplasmosis diseminada y afección pulmonar rara vez tienen tos, a pesar de que las radiografías muestran características consistentes con histoplasmosis pulmonar (Gabbert et al., 1984). En una revisión de casos, en ocho gatos con osteomielitis por $H$. capsulatum, ninguno mostró signos físicos obvios de enfermedad de las vías respiratorias (Gabbert et al., 1984).

Las presentaciones clínicas atípicas incluyen histoplasmosis diseminada que afecta solo al sistema óseo e histoplasmosis intestinal primaria, tanto en gatos jóvenes como en adultos (Rochat \& Cristal, 1999). Además, la histoplasmosis intestinal sin compromiso pulmonar concomitante puede manifestarse por signos clínicos como: caquexia crónica, fiebre, diarrea acuosa con hematoquecia y vómito (Stark, 1982).

\section{Diagnóstico diferencial}

La histoplasmosis debe diferenciarse de infecciones por micobacterias, protozoos y otros agentes fúngicos sistémicos y de neoplasias (Schaer, 2006). La histoplasmosis, al causar síntomas gastrointestinales, como la diarrea, puede confundir al médico clínico con otras enfermedades del intestino grueso, por ejemplo, colitis asociadas con las dietas (hipersensibilidad dietaria, colitis inducida por materiales extraños), colitis idiopática (colitis plasmocítica linfocitaria, colitis eosinofílica, colitis granulomatosa, colitis ulcerativa histiocítica de los perros boxer, colitis supurativa), colitis debido a protozoarios o parásitos (trichuriasis, ancilostomiasis, estrongiloidiasis, entoamebiasis, balantidiasis, giardiasis), colitis bacteriana (Salmonella spp., Campylobacter jejuni, Yersenia enterocolitica, Y. pseudotuberculosis, micobacterias, Clostridium perfringens, C. difficile), candidiasis, pitiosis gastrointestinal, prototecosis, intususcepción cecocólica, y colitis asociada a pancreatitis. También debe diferenciarse de infecciones o afecciones del intestino delgado como la enfermedad idiopática inflamatoria del intestino y el linfosarcoma intestinal (Ettinger \& Feldman, 2004).

La observación, en cualquier tipo de muestra clínica, de levaduras intracelulares de formas ovoides con gemación de base estrecha es muy sugestiva de histoplasmosis; sin embargo, debe tenerse en cuenta que algunas células pequeñas de Cryptococcus neoformans pobremente encapsuladas, así como también las células de Penicillium marneffei, Pneumocystis spp., Toxoplasma gondii y Leishmania donovani pueden crecer de modo intracelular y ser confundidas con H. capsulatum, dando lugar a errores de diagnóstico (Guimarães et al., 2006; Kauffman, 2007). 


\section{Métodos de diagnóstico}

Las pruebas generales de laboratorio clínico no son útiles en el diagnóstico de la infección dada la inespecificidad de los hallazgos (anemia leve, pancitopenia, aumento de la velocidad de sedimentación globular, hiperbilirrubinemia moderada e incremento de los niveles de lactato deshidrogenasa y fosfatasa alcalina, entre otros) (Aulakh et al., 2012; Brilhante et al., 2012; Bromel \& Sykes, 2005; Fernández-Andreu et al., 2011; Gilor et al., 2011; Schumacher et al., 2013; Taylor et al., 2012).

El diagnóstico de laboratorio se basa en técnicas de microscopía, cultivo y detección de antígenos y anticuerpos (Fernández-Andreu et al., 2011; Gilor et al., 2011; Gómez et al., 2005; Gómez \& Guida, 2010; Morales-Ruiz, 2010; Wheat, 2006). Las muestras suelen ser muy diversas, dependiendo de la forma clínica que se presente. Las más frecuentes son el esputo y otras secreciones respiratorias, sangre, médula ósea, exudado y raspado de lesiones cutáneas o mucocutáneas, orina, líquido cefalorraquídeo (LCR) y biopsias de distintos órganos (Fernández-Andreu et al., 2011).

Es importante destacar que la recolección del material que será procesado para diagnóstico microbiológico clásico debe realizarse en un recipiente estéril sin formol (Castañón-Olivares, 2014).

\section{Métodos directos \\ Examen directo}

El procedimiento con hidróxido de potasio, que por lo regular resulta útil para el diagnóstico de otras enfermedades fúngicas, no es de utilidad para la histoplasmosis. En el caso de infecciones diseminadas en animales inmunodeficientes, el examen microscópico de líquidos orgánicos estériles y de tejidos ayuda al diagnóstico, aunque se ha descrito hasta un $50 \%$ de falsos negativos en los exámenes histopatológicos (Gutiérrez et al., 2005, 2008). Las tinciones de Giemsa, May-Grünwald Giemsa (MGG) o Wright permiten observar las levaduras esféricas u ovoides, de 3 a $5 \mu \mathrm{m}$ de diámetro, rodeadas de una gruesa membrana dentro de macrófagos o monocitos; también puede haber levaduras extracelulares, debido a la destrucción de las células fagocitaria (Fig. 1). La observación de estas levaduras intracelulares teñidas de manera irregular compatibles con Histoplasma spp., en general, permite el diagnóstico de la micosis (Schumacher et al., 2013).

En una tinción de Gram, el $H$. capsulatum se identifica como Gram positivo; la pared no se tiñe y simula una cápsula clara que rodea el elemento levaduriforme. Esta tinción no permite observar las levaduras intracelulares y, por lo tanto, no permite el diagnóstico.
Otras tinciones histológicas, como el PAS y la coloración con plata de Gomori- Grocott, pueden teñir al $H$. capsulatum (Fig. 2). Sin embargo, un observador poco experimentado puede confundirlo con levaduras del género Candida, cuya morfología es parecida aunque es de mayor tamaño, se tiñe de forma homogénea y es extracelular (Taylor et al., 2012).

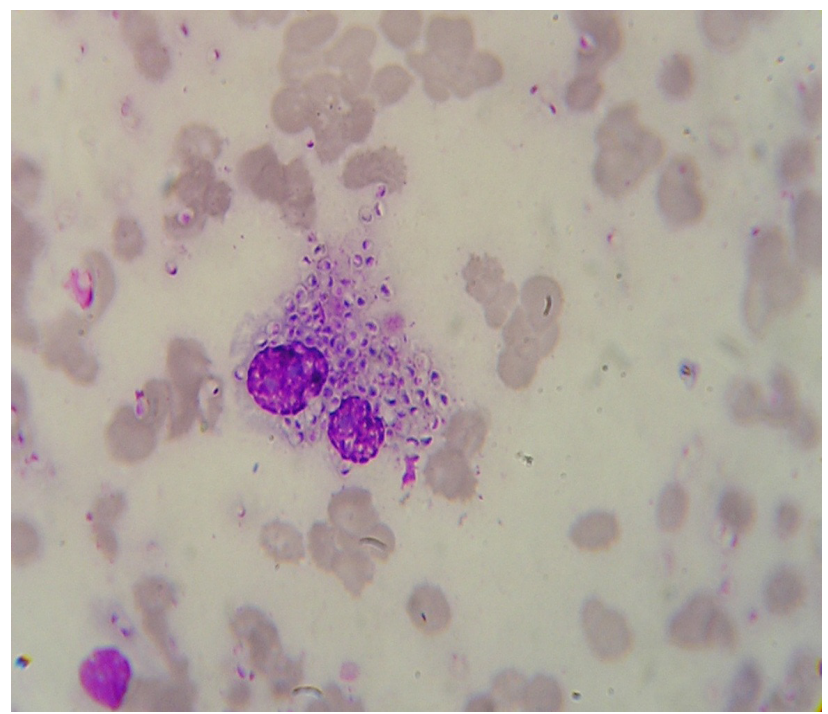

Figura 1. Raspado de lesión cutánea. Tinción de Giemsa (1000X). Gentileza del Dr. Gustavo Giusiano.

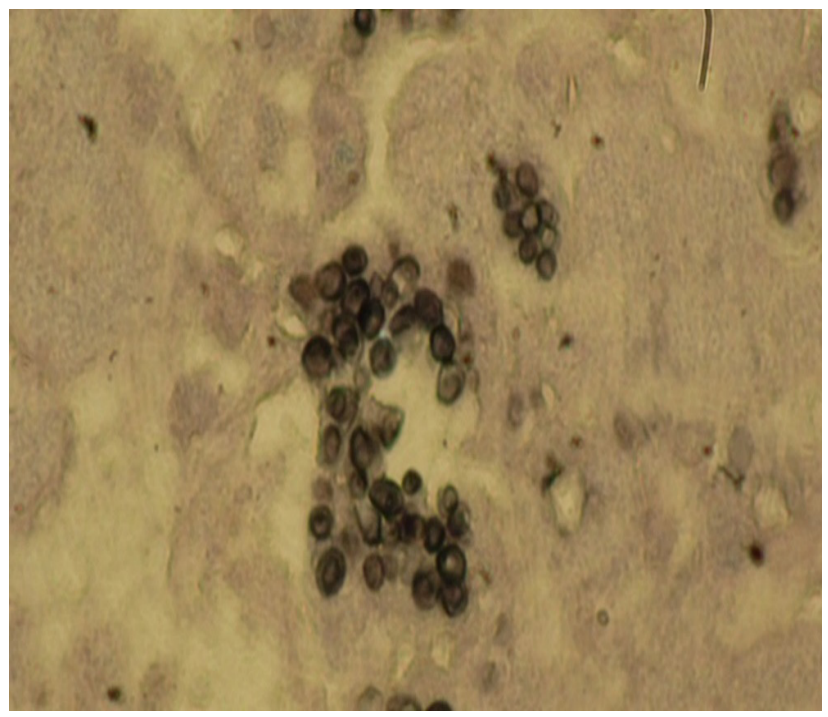

Figura 2. Levaduras de $\mathrm{Hc}$ var. capsulatum en hígado de Rattus norvegicus. Tinción de Gomori-Grocott (1000X). Gentileza del Dr. Roberto Suárez-Álvarez. Departamento de Micología. ANLIS-INEI "Dr. Carlos G. Malbrán".

Existen otros microorganismos que pueden ser confundidos con Histoplasma entre los que figuran Leishmania, Toxoplasma y Paracoccidioides. La diferenciación con Leishmania puede ofrecer dificultades, pero estos protozoarios poseen dos masas cromáticas, núcleo y blefaroplasto. También las levaduras de Histoplasma spp. deben diferenciarse de Toxoplasma. 
Finalmente, las formas pequeñas e intracelulares de Paracoccidioides spp. pueden ser confundidas con $\mathrm{H}$. capsulatum, pero la observación cuidadosa de varios campos microscópicos permite descubrir alguna forma multibrotante típica de Paracoccidioides spp. (Gómez \& Guida, 2010).

En los gatos es más probable encontrar levaduras en aspirados de médula ósea o linfonódulos y también en células procedentes de lavados traqueales o broncoalveolares. En los perros, en general, se encuentran más en biopsias, raspados rectales, aspirados de médula ósea, hígado, linfonódulos o bazo y también en células procedentes de lavados traqueales o broncoalveolares. No es frecuente el envío al laboratorio de aspirados de LCR y de lesiones óseas líticas (Morgan et al., 2004).

\section{Cultivo}

Cultivos a $28^{\circ} \mathrm{C}$. La muestra sospechosa de contener el agente se siembra en agar Sabouraud glucosa + antibiótico. Luego de una incubación de 15 a 21 días desarrolla la fase micelial del hongo, que macroscópicamente se caracteriza por presentar micelio aéreo algodonoso y blanco, el que con el tiempo puede tornarse parduzco.

En el examen microscópico de las colonias se puede diferenciar un micelio hialino, ramificado y tabicado, de 2 a $5 \mu \mathrm{m}$ de diámetro (Fig 3). La ramificación en algunos de los casos es lateral o raramente dicotómica. En general se observan macroconidios que nacen de conidióforos cortos, esféricos o piriformes, de 10 a $25 \mu \mathrm{m}$ de diámetro, con una pared celular gruesa y prolongaciones digitiformes. Los microconidios son piriformes y miden de 2 a $5 \mu \mathrm{m}$ de diámetro, con una pared lisa o rugosa. Estos microconidios son sésiles o se disponen sobre cortos conidióforos a lo largo de la hifa. Algunos cultivos pueden presentar macroco-

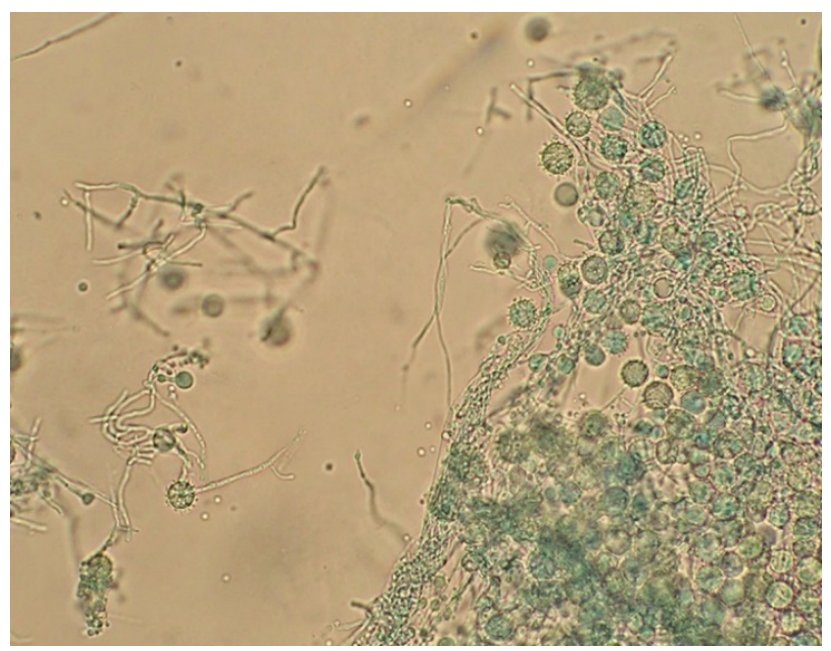

Figura 3. Fase micelial de $H$. capsulatum (400X). Gentileza del Dr. Gustavo Giusiano nidios atípicos de pared lisa. La técnica ideal para la observación del hongo poscultivo es la tinción con azul de lactofenol.

Cultivo a $37^{\circ} \mathrm{C}$. En agar infusión cerebro corazón se pueden observar macroscópicamente colonias de aspecto pastoso o seroso, lisas y de color blanco, crema o rosado. Tienen tendencia a revertir a la fase filamentosa y necesitan medios adicionados con sangre o cisteína para mantener la forma de levadura.

En el examen microscópico de las colonias desarrolladas a $37^{\circ} \mathrm{C}$ se pueden observar levaduras brotantes elípticas u ovales, de 2 a $5 \mu \mathrm{m}$ de diámetro. En estos cultivos suelen encontrarse formas de transición hacia la fase filamentosa, que se identifican como hifas cortas mezcladas con las levaduras. A veces se observan clamidoconidios intercalares y, en algunos casos, brotes intercalares o terminales. Esto sucede cuando los medios de cultivo son deficientes en nutrientes necesarios, por lo que la levadura tiende a desarrollar su fase micelial (López 2006). En la práctica clínica diaria no se recomienda realizar el cultivo del agente en laboratorios que no cuenten con rigurosas normas de bioseguridad, debido al riesgo para la salud pública que éste representa (Morgan et al., 2004).

\section{Detección de antígeno}

Las pruebas de detección de antígeno se han puesto en práctica solamente en humanos, debido a su complejidad de elaboración y a sus elevados costos. Las pruebas que detectan antígenos se consideran mucho más eficientes para el diagnóstico de la histoplasmosis. H. capsulatum es capaz de liberar un antígeno polisacarídico, que puede ser detectado en el suero, líquido pleural, lavado broncoalveolar, LCR y orina. Este método, aunque es específico para dicho antígeno, con una sensibilidad del $92 \%$ en muestras de orina y un $82 \%$ en muestras de suero, puede dar lugar a reactividad cruzada en muestras de orina de pacientes con otras micosis sistémicas (Wheat, 2006; Swartzentruber, 2009).

Las concentraciones de antígeno disminuyen en respuesta al tratamiento. En los pacientes inmunocomprometidos, tratados con anfotericina B, los niveles caen durante las primeras semanas de terapia y se estabilizan a niveles bajos durante el tratamiento de mantenimiento. En pacientes sin enfermedades que comprometan su estado de inmunocompetencia, la eliminación total del antígeno ocurre más rápidamente. La principal desventaja de este método, además de su elevado costo, es que solo se encuentra disponible en un laboratorio de EE. UU. (Fernández-Andreu et al., 2011).

Otros autores han ensayado diferentes métodos que también detectan antígenos en muestras clínicas, 
aunque no han sido comercializados. Mediante el empleo de anticuerpos monoclonales que reconocen la proteína de $70 \mathrm{kDa}$, Gómez et al. (2005) diseñaron un sistema inmunoenzimático capaz de detectar antígenos en muestras de suero y orina, aunque encontraron hasta un $20 \%$ de reacciones cruzadas en sueros de pacientes con aspergilosis, paracoccidioidomicosis y tuberculosis.

Hanzlicek et al. (2016) demostraron la utilidad del inmunoensayo enzimático (EIA, del inglés enzyme immunoassay) al evaluar la respuesta de gatos con histoplasmosis al tratamiento antifúngico e identificar una recaída o la remisión de la enfermedad. Los resultados de este estudio demostraron una disminución significativa de la concentración del antígeno en muestras de orina. La sensibilidad del EIA fue de $90 \%$ pero la especificidad fue solo de $64,6 \%$. Con una prueba positiva a antígeno se debería considerar la continuación del tratamiento pero, debido a su baja especificidad, deben tenerse en cuenta otros indicadores clínicos de remisión de la enfermedad para tomar la decisión de interrumpir el tratamiento. EI EIA no sustituye a las pruebas tradicionales para determinar la remisión de la enfermedad.

Otro método de detección de antígenos ha sido evaluado por Scheel et al. (2009), quienes utilizando un ELISA de captura con anticuerpos policlonales encontraron $81 \%$ de sensibilidad analizando muestras de orina de individuos con una enfermedad inmunomediada y con histoplasmosis confirmada mediante cultivo.

\section{Histopatología}

Las muestras provenientes de biopsias o material de necropsia se fijan en formol neutro al $10 \%$ y se procesan según la rutina de inclusión en parafina. Los estudios histopatológicos revelan lesiones piogranulomatosas, con numerosos microorganismos intracelulares.

Las tinciones especiales (PAS, fúngica de Gridley y metenaminargéntica de Gomori) son las que mejor demuestran la presencia de microorganismos en los tejidos (Morgan et al., 2004). Además, permiten observar la respuesta celular del hospedero: en individuos inmunodeprimidos, esta respuesta es pobre y se observan abundantes levaduras en el interior de los macrófagos, mientras que en los inmunocompetentes el hongo provoca una reacción granulomatosa, con predominio de células epitelioides y gigantes, en cuyo interior se observan las levaduras de $\mathrm{H}$. capsulatum. La sensibilidad de este método es muy baja en las formas autolimitantes y en la histoplasmosis pulmonar aguda; su valor se incrementa en las formas pulmonares crónicas y diseminadas (Kauffman et al., 2007; Guimarães et al., 2006). Con la técnica de PAS se diferencia Histoplasma de Leishmania y de Toxoplasma.
La reacción histológica típica es histiocitaria, con formación de un complejo primario análogo al de la tuberculosis (chancro de inoculación, linfangitis y adenopatía satélite), granuloma tuberculoide y tendencia a la fibrosis, que traducen un proceso defensivo. En los individuos con escasas defensas, se puede presentar una respuesta histiocitaria simple con numerosas levaduras o necrosis caseosa masiva.

La lesión granulomatosa pulmonar puede estar calcificada o activa. En la forma activa se observan numerosos nódulos grises de 0,5 a $1 \mathrm{~cm}$ de diámetro, formados por neutrófilos e histiocitos que contienen levaduras. Pueden existir focos de necrosis rodeados de linfocitos y células plasmáticas.

La observación en cualquier tipo de muestra clínica, proveniente de perros o gatos con sospecha de una enfermedad micótica sistémica, de levaduras intracelulares con las características antes mencionadas es sugestiva de histoplasmosis (Fernández-Andreu et al., 2011; Schumacher et al., 2013).

\section{Técnicas moleculares}

Debido a las dificultades que se presentan con el diagnóstico convencional de la histoplasmosis, en particular por la demora y la baja sensibilidad, en especial en algunas formas clínicas, en la actualidad se centran grandes esperanzas en las posibilidades que pueden brindar los métodos moleculares, particularmente las técnicas de PCR, ya que los métodos convencionales de detección como el cultivo requieren nivel de bioseguridad 3 y las pruebas de detección de antígeno muchas veces son inaccesibles (Wheat et al., 1986; Bialek et al., 2001).

En este sentido, uno de los primeros estudios fue publicado por Bialek et al (2001), quienes diseñaron una PCR anidada capaz de detectar ADN de $H$. capsulatum con elevada sensibilidad en muestras de tejidos y sangre de ratones infectados experimentalmente. Sin embargo, también detectó ácido nucleico de Blastomyces dermatitidis y Paracoccidioides brasiliensis. Mediante la detección de una pequeña región $18 S$ del ADN ribosomal, obtuvieron una buena sensibilidad y especificidad para el diagnóstico de la histoplasmosis.

Bialek et al. (2002) evaluaron dos PCR anidadas dirigidas a la amplificación de diferentes fragmentos genómicos. La primera amplifica un fragmento del ADN ribosomal del gen $18 \mathrm{~S}$ y la segunda amplifica la secuencia genómica de la proteína HC100. Así observaron que la especificidad y la sensibilidad de las pruebas diagnósticas son idénticas. Además, comprobaron la especificidad de la PCR anidada dirigida a la proteína $\mathrm{HC} 100$ al enfrentarla con los ácidos nucleicos de $B$. dermatitidis y $P$. brasiliensis, los cuales 
comparten la misma secuencia génica del gen $18 \mathrm{~S}$ de H. capsulatum (Porta et al., 1999).

Bracca et al. (2003) desarrollaron una PCR semianidada que detecta un gen codificante del antígeno $\mathrm{H}$ de $\mathrm{H}$. capsulatum, que sirvió para el diseño de 3 oligonucleótidos a los que denominaron Hc1, Hc2 y Hc3. Estos sirvieron para la identificación específica de $H$. capsulatum, sin presentar reacciones cruzadas con ninguna bacteria u hongo. La técnica fue empleada en muestras de pacientes con histoplasmosis diagnosticada por medio del cultivo del agente. La PCR semianidada detecta material genético de $\mathrm{H}$. capsulatum en pacientes con cultivo negativo, por lo que se la considera como una buena técnica de diagnóstico.

Los principales antígenos de diagnóstico de H. capsulatum son el H y el M. Guedes et al. (2003) propusieron una prueba diagnóstica basada en el diseño de oligonucleótidos para amplificar la secuencia genómica del antígeno $\mathrm{M}$ del hongo. La prueba se caracterizó por su alta sensibilidad y su especificidad del $100 \%$ al contrastarla con Paracoccidioides brasiliensis, Candida spp., Sporothrix schenckii, Cryptococcus neoformans, Blastomyces dermatitidis, Coccidioides immitis, Aspergillus niger y Aspergillus fumigatus, indicando que la técnica es ideal para la identificación de $H$. capsulatum var. capsulatum.

La PCR anidada HcP100 ha sido evaluada en distintas partes del mundo en el diagnóstico de histoplasmosis. Maubon et al. (2007) evaluaron esa técnica molecular frente al examen microscópico directo y el cultivo (estándar de oro), dando como resultado un $100 \%$ de especificidad y sensibilidad en muestras clínicas de pacientes con sospecha de histoplasmosis. Toranzo et al. (2009) evaluaron la misma PCR anidada con muestras de sangre entera de pacientes con diagnóstico de histoplasmosis, pacientes con infecciones fúngicas diversas y pacientes sanos como casos controles, obteniendo como resultado un $89 \%$ de sensibilidad y un $96 \%$ de especificidad para el diagnóstico de la enfermedad en muestras de sangre entera. El único falso positivo que detectó la prueba fue el de un paciente con una infección por Mycobacterium avium-intracellulare. Por otra parte, Muñoz et al. (2010) realizaron una evaluación en pacientes con sospecha de histoplasmosis, pacientes con enfermedad respiratoria con cultivo negativo a hongos, pacientes con infecciones diversas y pacientes sanos, aplicando la PCR anidada dirigida al gen codificante de la proteína HC100. Con este método obtuvieron una sensibilidad del $100 \%$ y una especificidad del $92,4 \%$ y $95,2 \%$, en coincidencia con los resultados anteriormente descritos que indican que la PCR anidada es una herramienta útil para el diagnóstico rápido y eficaz de la histoplasmosis en zonas endémicas.
La PCR en tiempo real (PCR-RT) es una de las técnicas vanguardistas que ha sido utilizada para la detección de diversos agentes patógenos. MartagonVillamil et al. (2003) desarrollaron la primera PCRRT para la identificación de $H$. capsulatum dirigida a la secuencia ITS-1 (internal transcribed spacer) y aplicaron los cebadores Hcap-F y Hcap-R hibridados con isotiocianato de fluoresceína. La nueva técnica se puso a prueba con 107 aislamientos micóticos, de los cuales 34 eran $H$. capsulatum. Se comprobó la especificidad de la misma con otros hongos como Candida spp., Blastomyces dermatitidis, Aspergillus spp. y Cryptococcus spp., obteniendo un $100 \%$ de especificidad y de sensibilidad, lo que la posiciona como una prueba confiable para el diagnóstico de la histoplasmosis.

Buitrago et al. (2007) evaluaron la PCR-RT descrita por Martagon-Villamil et al. (2003); utilizaron para el diseño de los iniciadores y sondas las regiones de ITS y eligieron fragmentos pertenecientes a la zona ITS-1. Se diseñó un control interno de la técnica de PCR, que consistía en la inclusión de otro oligonucleótido en la reacción, con secuencia complementaria al de los iniciadores y la sonda, pero con algunos cambios en las secuencia, lo cual sirvió para detectar productos de amplificación sin producción de fluorescencia. La sensibilidad y la especificidad de la prueba fueron de $78,6 \%$ y $100 \%$, respectivamente, para muestras de secreciones respiratorias, aspirados medulares y muestras de suero. Cabe recalcar que las muestras de elección para la PCR-RT son las secreciones respiratorias y los aspirados medulares, con los cuales se obtienen una sensibilidad y una especificidad del $100 \%$.

Babady et al. (2011) detallaron un ensayo PCRRT capaz de identificar simultáneamente $B$. dermatitidis e $H$. capsulatum empleando los iniciadores BD1, 2, 3, 4 y HC1, 2, 3, 4, respectivamente. La extracción se realizó partiendo de muestras de cultivo y directamente de muestras clínicas, tales como secreciones respiratorias, tejido fresco, sangre, médula ósea y líquido cefalorraquídeo. No se procesaron muestras de orina, ya que en pacientes con histoplasmosis diseminada con frecuencia no se encuentra ADN de Histoplasma en la misma. En esos casos es recomendable el uso del ensayo de antígeno de $H$. capsulatum. Se demostró una sensibilidad de $73 \%$ y una especificidad de $100 \%$ para la detección de $H$. capsulatum en muestras clínicas.

Simon et al. (2010) evaluaron la PCR-RT comparándola con otras técnicas, tales como las serológicas, el examen directo y el cultivo (estándar de oro), obteniendo un $95,4 \%$ de sensibilidad y un $96 \%$ de especificidad. La validación del protocolo se realizó gracias a un estudio multicéntrico que incluyó 
5 laboratorios a los que se les entregaron 10 muestras para identificar. Los resultados fueron óptimos. No encontraron falsos positivos y la especificidad alcanzó el $100 \%$. Sin embargo, la sensibilidad fue del $43 \%$ en un laboratorio donde se aplicó la PCR-RT dirigida a secuencias específicas (SCARS markers) (Buitrago et al., 2013).

Fernández-Andreu et al. (2011) indicaron que sería muy beneficioso estandarizar una prueba que permita identificar $H$. capsulatum var. capsulatum en muestras ambientales; una técnica con estas características sería una herramienta útil para fortalecer estudios epidemiológicos y de salud pública.

\section{Métodos indirectos \\ Detección de anticuerpos}

Las pruebas que detectan anticuerpos han sido de gran valor en el diagnóstico de la histoplasmosis, no solo por su relativa rapidez en comparación con los métodos de cultivo e identificación, sino también porque, en muchas ocasiones, son la primera y a veces la única evidencia de infección (Freitas et al., 2009). Las más empleadas han sido la inmunodifusión doble, la fijación del complemento y la técnica de ELISA indirecta. La prueba cutánea de la histoplasmina está disponible pero no es muy conocida por haber sido superada por las otras técnicas serológicas descritas.

En las zonas endémicas, entre el 50 y el $80 \%$ de adultos presenta positividad a la prueba cutánea de histoplasmina; aunque menos del $5 \%$ de las personas desarrollan la enfermedad sintomática, después de un bajo nivel de exposición, la tasa de ataque puede ser superior al $75 \%$ después de una exposición prolongada (Wheat 2003; Wheat et al., 2004). Las altas tasas de histoplasmina positiva en humanos de zonas endémicas plantean el interrogante sobre cuál podría ser el porcentaje de animales de la misma zona positivos a histoplasmina.

En 1939, De Monbreum comunicó el primer caso de histoplasmosis en un perro. A partir de entonces, diversos investigadores buscaron comprobar la presencia del hongo en los animales mediante métodos fáciles y prácticos. Prior et al. realizaron una evaluación de la reacción de la histoplasmina positiva en perros, encontrando que la reacción positiva era similar a la producida por tuberculina en el ganado bovino positivo a Mycobacterium bovis (Prior et al., 1949).

Okudaira et al. (1962) estudiaron las características de la reacción cutánea a la histoplasmina en perros, constatando la formación de vesículas y erosiones y, microscópicamente, una moderada a abundante infiltración de células mononucleares y neutrófilos. La intensidad de esta respuesta varió cuantitativamente en animales negativos y positivos.

En San Pablo, Brasil, se realizó un estudio epidemiológico para identificar el porcentaje de seropositividad en diferentes mamíferos del zoológico mediante la prueba cutánea de histoplasmina. Se encontró un $44,8 \%$ de reacciones positivas en total: de este valor, un $15,1 \%$ correspondió a los Cebidae, $6,2 \%$ a los Callithricidae, $86,5 \%$ a los Procyonidae y $50 \%$ a los Felidae (Costa et al., 1994).

Las pruebas serológicas se utilizan en perros y gatos de áreas endémicas para establecer un diagnóstico presuntivo cuando las manifestaciones clínicas sugieren la enfermedad pero el microorganismo no se ha logrado detectar. Se cree que los anticuerpos precipitantes representan la inmunoglobulina $\mathrm{M}$ y se detectan 2-4 semanas después de la infección inicial en animales. La prueba de anticuerpos precipitantes puede ser negativa y convertirse en positiva cuando la enfermedad se disemina (Morgan et al., 2004).

La inmunodifusión doble se considera una prueba sencilla, económica y muy específica, debido a la aparición de las bandas de precipitación $\mathrm{H}$ y $\mathrm{M}$ entre las 4 y 6 semanas después de la exposición, aunque su sensibilidad es baja. La presencia de una banda M indica una infección activa o pasada o la aplicación reciente de una prueba intradérmica de histoplasmina. La banda $\mathrm{H}$ aparece después de la banda $\mathrm{M}$ e indica infección activa (Fernández-Andreu et al., 2011).

Los anticuerpos anti-M pueden persistir durante años en el suero del paciente, mientras que los anti-H tienden a desaparecer mucho más rápidamente. La prueba de fijación del complemento es más sensible y menos específica que la inmunodifusión, pero requiere de gran experiencia y, en general, está siendo abandonada por la mayoría de los laboratorios por su complejidad (Morgan et al., 2004).

Los anticuerpos fijadores del complemento aparecen más tardíamente que las precipitinas (30 días después del contacto infectante). En las primoinfecciones leves, esta prueba es negativa, mientras que en las moderadas se vuelve negativa luego de mostrar una leve positividad. Es una técnica ideal para seguir la evolución de la enfermedad (Gómez \& Guida, 2010). Un título de 1:32 se considera positivo, mientras que los títulos de 1:8 y 1:16 se consideran débilmente positivos y, en algunos casos, indican una infección anterior, en especial en individuos de áreas endémicas. Si se pretende alcanzar una mayor sensibilidad se recomienda realizar de manera simultánea la FC y la ID (Ettinger \& Feldman, 2004; Gómez \& Guida, 2010; Morgan et al., 2004).

Las pruebas serológicas son positivas en, aproximadamente, el $71 \%$ de las formas diseminadas de histoplasmosis, en el $100 \%$ de las pulmonares 
crónicas y en el $98 \%$ de las pulmonares agudas y autolimitadas. Sin embargo, en individuos inmunocomprometidos la positividad es mucho menor (FernándezAndreu et al., 2011).

Los ensayos inmunoenzimáticos también han sido empleados en el diagnóstico de histoplasmosis, aunque de manera limitada, y han mostrado buena sensibilidad aunque menor especificidad que las pruebas de inmunoprecipitación. Las pruebas se tornan positivas a los 4-7 días del contacto con el agente y alcanzan su título máximo a las 2-3 semanas, valores que luego decrecen y persisten bajos. Son útiles para diagnosticar neumonitis de primoinfección con evoluciones de menos de 1 año (Gómez \& Guida, 2010).

En todos los casos, la interpretación de las pruebas serológicas debe realizarse integrando sus resultados con los datos clínico-epidemiológicos y micológicos. También se han desarrollado pruebas de hemaglutinación pasiva, inmunofluorescencia, inmunoelectroforesis e inmunoblotting, entre otras (Gómez \& Guida 2010).

\section{Tratamiento}

Para el tratamiento, las drogas de primera elección son el ketoconazol y el itraconazol. El primero es suministrado a dosis de $5-15 \mathrm{mg} / \mathrm{kg}$ vía oral (v.o.) cada $12 \mathrm{~h}$ y el segundo a dosis de $5-10 \mathrm{mg} / \mathrm{kg}$ v.o. cada $24 \mathrm{~h}$. Los tiempos de retiro de los fármacos antimicóticos dependen mucho del paciente y del tipo de enfermedad. Para procesos pulmonares es de esperar una pronta curación, pero en casos de enfermedades sistémicas diseminadas el tiempo de retiro puede extenderse hasta 12 meses (Morgan et al., 2004). La administración de ketoconazol en animales durante mucho tiempo debe ser evaluada mensualmente mediante análisis químico del suero completo, incluido el perfil hepático. No debe indicarse en hembras reproductoras, debido a que el ketoconazol es teratogénico y hepatotóxico. Para las formas sistémicas es útil la anfotericina $\mathrm{B}$, por vía intravenosa, en solución glucosada al $5 \%$, a razón de $0,5 \mathrm{mg} / \mathrm{kg} / \mathrm{d}$ ía administrada durante $4-6$ horas durante 6 semanas (Gómez \& Guida, 2010).

La enfermedad pulmonar puede remitir de forma espontánea. Sin embargo, igualmente se recomienda el tratamiento antifúngico para evitar posibles cuadros de cronicidad.

El tratamiento recomendado para la histoplasmosis felina se basa en el itraconazol, a dosis de $5 \mathrm{mg} /$ $\mathrm{kg}$ v.o. cada $12 \mathrm{~h}$ durante, al menos, 2-4 meses. La biodisponibilidad de la cápsula es variable y algunos gatos pueden requerir dosis de hasta $10 \mathrm{mg} / \mathrm{kg}$ v.o. cada $12 \mathrm{~h}$. Además, se debe suplementar con $250 \mathrm{\mu g}$ de cobalamina, por vía subcutánea, durante 7 días, dada la comprobada deficiencia de esta vitamina, tanto en gatos sanos como en enfermos (Reed et al., 2007). El ketoconazol es eficaz en un tercio de los gatos que padecen la enfermedad. La anfotericina $B$ puede ser agregada al tratamiento cuando están gravemente afectados.

En caninos el tratamiento ideal es el itraconazol $10 \mathrm{mg} / \mathrm{kg}$ v.o. cada $12 \mathrm{~h}$. En casos graves como es el caso de animales inmunodeficientes, se aconseja utilizar anfotericina B. La administración de corticoesteroides está indicada en perros con obstrucción de las vías respiratorias por aumento de tamaño de los linfonóduloss hiliares (Morgan et al., 2004).

\section{Algoritmo de diagnóstico}

En la figura 4 se muestra un algoritmo simple para arribar al diagnóstico de histoplasmosis. Es recomendable que se obtengan resultados positivos de tres o más pruebas para confirmar el diagnóstico.

\section{Discusión}

Histoplasma spp., un hongo dimórfico del cual según el lugar de origen del aislamiento se han identificado tres variedades taxonómicas $(H$. capsulatum: var. capsulatum, var. duboisii y var. farciminosum), es el agente causal de la histoplasmosis.

La formación de microconidios promueve la diseminación y contagio; además, la resistencia al fagolisosoma de los macrófagos favorece la presentación de enfermedad pulmonar (Woods et al., 2003). Sin embargo, pueden verse afectados otros sistemas, tanto en caninos como en felinos, como el tracto gastrointestinal, linfonódulos, hígado, bazo, médula ósea, ojos y glándulas adrenales.

Esta infección fúngica puede afectar a una gran variedad de mamíferos, siendo más susceptibles los felinos y los caninos menores de 4 años (Morgan et al., 2004). La enfermedad presenta dos fases, una primaria que puede ser pulmonar o cutánea y otra progresiva que corresponde a la forma diseminada.

En caninos la histoplasmosis se evidencia principalmente con signología gastrointestinal, esplenomegalia, hepatomegalia y linfadenopatía, a diferencia de los felinos, en los cuales las alteraciones gastrointestinales son poco frecuentes. No obstante, es posible que haya presentaciones atípicas de histoplasmosis diseminada con alteraciones del sistema óseo o histoplasmosis intersticial primaria (Rochat \& Cristal, 1999).

La inespecificidad de los signos clínicos hace que entre los diagnósticos diferenciales se incluyan las infecciones por micobacterias, protozoos, otras micosis sistémicas y neoplasias. Se han evaluado distintos métodos directos e indirectos de diagnóstico 


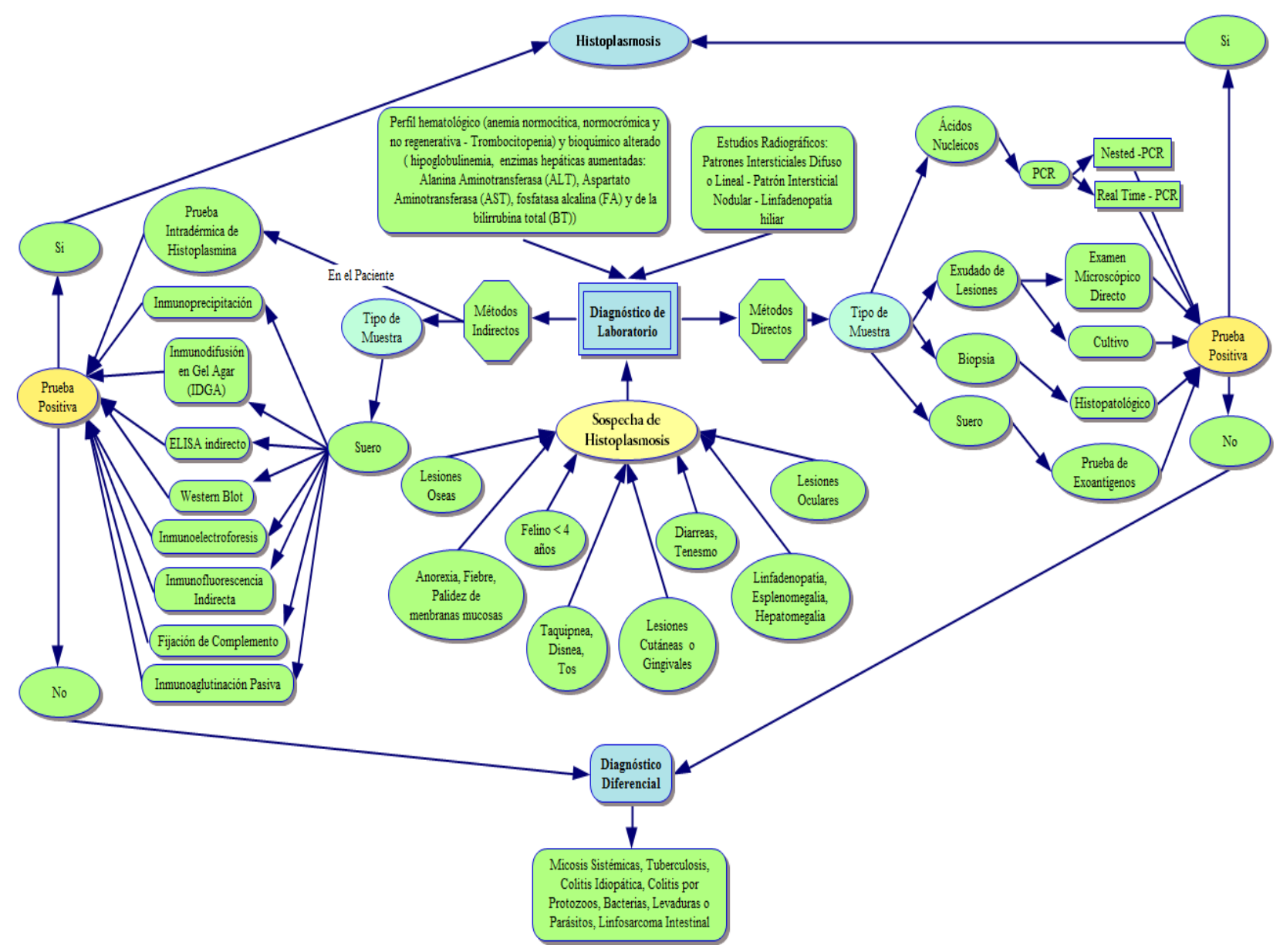

Figura 4. Algoritmo para el diagnóstico de la histoplasmosis

a partir de una variedad de muestras clínicas, tales como esputo, sangre, médula ósea, exudado y raspado de lesiones cutáneas o mucocutáneas, orina, líquido cefalorraquídeo y biopsias de distintos órganos.

Los métodos indirectos, utilizados para el diagnóstico de histoplasmosis son pruebas rápidas, en comparación con el cultivo, y detectan anticuerpos. Entre los métodos diagnósticos directos se encuentran técnicas como microscopía directa, detección de antígeno, histopatología y métodos moleculares.

Utilizando la microscopía directa es probable que se cometan errores de diagnóstico por una confusión de Histoplasma con otros microorganismos como Candida spp., Leishmania, Toxoplasma y Paracoccidioides. Los métodos de cultivo representan un alto riesgo de contagio para el personal de laboratorio y es necesario un nivel de bioseguridad 3. En consecuencia, en la actualidad se opta por métodos moleculares que ofrecen resultados rápidos y precisos para la identificación de esta micosis. Entre los métodos moleculares empleados se encuentran PCR anidada para la amplificación de un fragmento del ADN ribosomal del gen $18 S$ y para la secuencia genómica de la proteína HC100, PCR semianidada para detectar el gen del antígeno $\mathrm{H}$ y la PCR-RT que posee una elevada sensibilidad y especificidad y es considerada como una herramienta valiosa para estudios epidemiológicos.

\section{Bibliografía}

Abidon-Aidé M. 2009. Histoplasmosis. Revista de Neumología de Brasil. 35:1145-51.

Aulakh HK, Aulakh KS, Troy GC. 2012. Feline histoplasmosis: a retrospective study of 22 cases (1986-2009). Journal of the American Animal Hospital Association. 48(3):182-7.

Babady NE, Buckwalter S P, Hall L, Le Febre K M, Binnicker M, Wengenack NL. 2011. Detection of Blastomyces dermatitidis and Histoplasma capsulatum from culture isolates and clinical specimens by use of real-time PCR. Journal of Clinical Microbiology. 49(9): 3204-8. doi:10.1128/JCM.00673-11

Bialek R, Feucht A, Aepinus C, Just-Nübling G, Robertson VJ, Knobloch J, Hohle R. 2002. Evaluation of two nested PCR assays for detection of Histoplasma capsulatum DNA in human tissue. Journal of Clinical Microbiology. 40(5):1644-7.

Bialek R, Fischer J, Feucht A, Najvar LK, Dietz K, Knobloch J, Graybill JR. 2001. Diagnosis and monitoring of murine histoplasmosis by a nested PCR assay. Journal of Clinical Microbiology. 39(4):1506-9. doi:10.1128/JCM.39.4.15061509.2001

Bracca A, Tosello ME, Girardini JE, Amigot SL, Gómez C, Serra E. 2003. Molecular detection of Histoplasma capsulatum var. capsulatum in human clinical samples. Journal of Clinical Microbiology. 41(4):1753-5. 
Brilhante RS, Coelho CG, Sidrim JJ, de Lima RA, Ribeiro JF, de Cordeiro RA, Rocha, MF. 2012. Feline histoplasmosis in Brazil: clinical and laboratory aspects and a comparative approach of published reports. Mycopathologia. 173(2-3), 193-7. doi:10.1007/s11046-011-9477-8

Bromel C, Sykes JE. 2005. Histoplasmosis in dogs and cats. Clinical Techniques in Small Animal Practice. 20(4):227-32.

Buitrago M J, Canteros CE, Frías De León G, González Á, Marques-Evangelista de Oliveira M, Muñoz CO, CuencaEstrella, M. 2013. Comparison of PCR protocols for detecting Histoplasma capsulatum DNA through a multicenter study. Revista Iberoamericana de Micología. 30(4),256-60. doi:10.1016/j.riam.2013.03.004

Buitrago MJ, Gómez-López A, Monzón A, Rodríguez-Tudela JL, Cuenca-Estrella M. 2007. Assessment of a quantitative PCR method for clinical diagnosis of imported histoplasmosis. Enfermedades Infecciosas y Microbiología Clínica. 25(1):16-22.

Martinez Cepeda GE. Micosis Sistémicas Endémicas. Trabajo final, Especialización de Diagnóstico Veterinario de Laboratorio, Facultad de Ciencias Veterinarias. Universidad nacional de La Plata. 2012.

Carme B, Hayette MP, Itoua Ngaporo A, Ngolet A, Darozzin F, Moyikoua A, Lehenaff YM. 1993. Histoplasmose africiaine à Histoplasma duboisii (Histoplasma capsulatum var. duboisii): quatorze cas congolais observés en 10 ans (1981-1990Journal de Mycologie Médicale.3:67-73.

Castañón-Olivares L. 2014. Histoplasmosis. Departamento de Microbiología y Parasitología - Recursos de Micología. [ONLINE] Disponible en: http://www.facmed.unam.mx/deptos/microbiologia/micologia/histoplsmosis.html. [Consultado 30/05/2014]

Costa EO, Diniz LS, Netto CF, Arruda C, Dagli ML. 1994. Epidemiological study of sporotrichosis and histoplasmosis in captive Latin American wild mammals. Sao Paulo, Brazil. Mycopathologia. 125(1):19-22.

Davies C, Troy GC. 1996. Deep mycotic infections in cats. Journal of the American Animal Hospital Association.32(5):380-91.

Ettinger SJ, Feldman EC, eds. Micosis sistémicas-Histoplasmosis. En: Ettinger SJ, 2004. Textbook of Veterinary Internal Medicine. $6^{\circ}$ Ed. St. Louis, Missouri: Elsevier Saunders, pp. 680-682.

Fernández-Andreu C, Illnait-Zaragozí M, Martínez-Machín G, Perurena-Lancha M, Monroy-Vaca E. 2011. Una actualización acerca de histoplasmosis. Revista Cubana de Medicina. 63(3):20.

Freitas RS, Carvalho-Vivi JO, Zamboni IM, Assis CM, CostaMartins JE, VicentiniMoreira AP. 2009. The importance of serological assays in diagnosing acute pulmonary histoplasmosis. The Journal of Venomous Animals and Toxins Including Tropical Diseases. 15:278-88

Gabbert NH, Campbell TW, Beiermann RL. 1984. Pancytopenia associated with disseminated histoplasmosis in a cat. Journal of the American Animal Hospital Association. 20(1): 119-22.

Gilor C, Ridgway MD, Singh K. 2011. DIC and granulomatous vasculitis in a dog with disseminated histoplasmosis. Journal of the American Animal Hospital Association. 47(3):26-30.

Gómez J, Orio-Hernández M, Bilbao-Garagoitia A, García-
Rodríguez J, Baquero F. 2005. Histoplasmosis diseminada. Notas Clínicas. 63(3):249-52.

Gómez N, Guida N. Histoplasmosis. En: Gómez N, Guida N. 2010. Enfermedades infecciosas de los caninos y felinos. Buenos Aires, Ed. Inter-Médica, pp. 273-7.

Guedes HL, Guimarães AJ, Muniz M de M, Pizzini CV, Hamilton AJ, Peralta JM, Deepe GS Jr, Zancopé-Oliveira RM. 2003. PCR assay for identification of Histoplasma capsulatum based on the nucleotide sequence of the $M$ antigen. Journal of Clinical Microbiology. 41(2):535-9.

Gugnani, HC, Muotoe-Okafor F. 1997. African histoplasmosis: a review. Revista Iberoamericana de Micología. 14(4),155-9.

Guimarães AJ, Nosanchuk JD, Zancope-Oliveira RM. 2006. Diagnosis of histoplasmosis. Brazilian Journal of Microbiology. 37(1):1-13.

Gutiérrez ME, Canton A, Connolly P, Zarnowski R, Wheat LJ. 2008. Detection of Histoplasma capsulatum antigen in Panamanian patients with disseminated histoplasmosis and AIDS. Archive of "Clinical and Vaccine Immunology. 15(4):681-3.

Gutiérrez ME, Canton A, Sosa N, Puga E, Talavera L. 2005. Disseminated histoplasmosis in patients with AIDS in $\mathrm{Pa}-$ nama: a review of 104 cases. Clinical Infectious Disease. 40(8):1199-202.

Hanzlicek AS, Meinkoth JH, Renschler JS, Goad C, Wheat LJ. 2016. Antigen concentrations as an indicator of clinical remission and disease relapse in cats with histoplasmosis. Journal of Veterinary Internal Medicine. 30(4):1065-73. doi:10.1111/jvim.13962.

Hearn VM. Structure and function of the fungal cell wall. En: Jacobs PH, Nall L, eds, 1997. Fungal diseases. Biology, immunology, and diagnosis. New York: Marcel Dekker, Inc., pp. 27-60.

Kagawa Y, Aoki S, Iwatomi T, Yamaguchi M, Momiyama N, Hirayama K, Taniyama H. 1998. Histoplasmosis in the Skin and Gingiva in a Dog. Journal of Veterinary Medical Science. 60(7), 863-5. doi:10.1292/jvms.60.863

Kasuga T, Taylor J, White T. 1999. Phylogenetic relationships of varieties and geographical groups of the human pathogenic fungus Histoplasma capsulatum Darling. Journal of Clinical Microbiology. 37(3):653-63.

Kasuga T, White TJ, Koenig G, Mcewen J, Restrepo A, Castañeda E, Da Silva Lacaz C, Heins-Vaccari EM, de Freitas RS, Zancopé-Oliveira RM, Qin Z, Negroni R, Carter DA, Mikami Y, Tamura M, Taylor ML, Miller GF, Poonwan N, Taylor JW. 2003. Phylogeography of the fungal pathogen Histoplasma capsulatum. Molecular Ecology. 12(12), 3383401. doi:10.1046/j.1365-294X.2003.01995.x

Kauffman CA. 2007. Histoplasmosis: a clinical and laboratory update. Clinical Microbiology Reviews. 20(1):115-32.

Kwon-Chung KJ, Bennett JE, 1992. Infections due to Trichosporon and other miscellaneous yeast-like fungi. Medical Mycology. Malvern: Lea \& Febiger, pp. 768-82.

López CE. 2006. Dimorfismo y patogenia de Histoplasma capsulatum. Revista Argentina de Microbiologia. 38:235-42

Meadows RL, MacWilliams PS, Dzata G, Delauche AJ. 1992. Diagnosis of histoplasmosis in a dog by cytologic examination of CSF. Veterinary Clinical Pathology. 21(4), 122-4. doi:10.1111/j.1939-165X.1992.tb00598.x 
Martagon-Villamil J, Shrestha N, Sholtis M, Isada CM, Hall GS, Bryne T, Lodge BA, Reller LB, Procop GW. 2003. Identification of Histoplasma capsulatum from culture extracts by real-time PCR. Journal of Clinical Microbiology. 41(3):1295-8.

Maubon D, Simon S, Aznar C. 2007. Histoplasmosis diagnosis using a polymerase chain reaction method. Application on human samples in French Guiana, South America. Diagnostic Microbiology and Infectious Disease. 58(4):441-4.

Mitchell M, Stark DR. 1980. Disseminated canine histoplasmosis: a clinical survey of 24 cases in Texas. The Canadian Veterinary Journal. 21(3):95-100.

Morales-Ruiz J. Histoplasmosis. 2010. Revista de la Facultad de Medicina. 4(3):1-3.

Morgan RV, Bright RM, Swartout MS. Micosis sistémicas Histoplasmosis. En: Morgan RV, 2004. Clínica de pequeños animales. $4^{\circ}$ Ed. Madrid: Elsevier, pp. 1079-81.

Muñoz B, Martínez MA, Palma G, Ramírez A, Frías MG, Reyes MR, Taylor ML, Higuera AL, Corcho A, Manjarre ME. 2010. Molecular characterization of Histoplasma capsulatum isolated from an outbreak in treasure hunters. BMC Infectious Diseases. 10:264

Nishifuji K, Ueda Y, Sano A, Kadoya M, Kamei K, Sekiguchi M, Nishimura K, Iwasaki T. 2005. Interdigital involvement in a case of primary cutuneous canine histoplasmosis in Japan. Journal of Veterinary Medicine. A, Physiology, Pathology, Clinical Medicine. 52:478-80.

Okudaira M, Straub M, Schwarz J. 1962. The histologic features of the histoplasmin skin test in dogs. American Journal of Pathology. 40:721-7.

Peterson PB, Willard MD. 2003. Protein-losing enteropathies. Veterinary Clinics of North America: Small Animal Practice. 33(5):1061-82.

Peterson SW, Sigler L. 1998. Molecular genetic variation in Emmonsia crescens and Emmonsia parva, etiologic agents of adiaspiromycosis, and their phylogenetic relationship to Blastomyces dermatitidis (Ajellomyces dermatitidis) and other systemic fungal pathogens. Journal of Clinical Microbiology. 36:2918-25.

Porta A, Colonna-Romano S, Callebaut I, Franco A, Marzullo L, Kobayashi GS, Maresca B. 1999. An homologue of the human $100-\mathrm{kDa}$ protein (p100) is differentially expressed by Histoplasma capsulatum during infection of murine macrophages. Biochemical and Biophysical Research Communications. 254(3):605-13.

Prior JA, Cole CR, Torbet V. 1949. An evaluation of the histoplasmin reaction in the detection of naturally occurring histoplasmosis in dogs. Public Health Reports. 64(48):1562-6.

Reed N, Gunn-Moore D, Simpson K. 2007. Cobalamin, folate and inorganic phosphate abnormalities in ill cats. Journal of Feline Medicine and Surgery. 9(4):278-88.

Reginato A, Giannuzzi P, Ricciardi M, De Simone A, Sanguinetti M, Porcellato I, Mandara MT. 2014. Extradural spinal cord lesion in a dog: first case study of canine neurological histoplasmosis in Italy. Veterinary Microbiology. 170(3-4), 451-5. doi:10.1016/j.vetmic.2014.02.024

Rippon JW, 1988. Medical Mycology. Philadelphia: WB Saunders Company. pp. 154-275.

Rochat MC, Crystal MA. 1999. Challenging cases in internal medicine (what's your diagnosis? Osteomyelitis caused by histoplasmosis in a cat). Veterinary Medicine. 94:520-527.

Sánchez-Alemán MA. 2009. Histoplasmosis, la micosis del viajero. Enfermedades Infecciosas y Microbiología. 29:5.

Schaer M. Enfermedades Infecciosas - Histoplasmosis. En: Schaer M, 2006. Medicina clínica del perro y el gato. $8^{\circ} \mathrm{Ed}$. Madrid: Ed Elsevier, p. 52.

Scheel CM, Samayoa B, Herrera A, Lindsley MD, Benjamin L, Reed Y, Hart J, Lima S, Rivera BE, Raxcaco G, Chiller T, Arathoon E, Gómez BL. 2009. Development and evaluation of an enzyme-linked immunosorbent assay to detect Histoplasma capsulatum antigenuria in immunocompromised patients. Clinical and Vaccine Immunology. 16(6):852-8.

Schumacher LL, Love BC, Ferrell M, De Silva U, Fernando R, Ritchey JW. 2013. Canine intestinal histoplasmosis containing hyphal forms. Journal of Veterinary Diagnostic Investigation. 25(2):304-7.

Simon S, Verón V, Boukhari R, Blanchet D, Aznar C. 2010. Detection of Histoplasma capsulatum DNA in human samples by real-time polymerase chain reaction. Diagnostic Microbiology and Infectious Disease. 66(3):268-73.

Stark DR. 1982. Primary gastrointestinal histoplasmosis in a cat. Journal of the American Animal Hospital Association. 18:154-156

Swartzentruber S, Rhodes L, Kurkjian K, Zahn M, Brandt ME, Connolly P, Wheat LJ. 2009. Diagnosis of acute pulmonary histoplasmosis by antigen detection. Clinical Infectious Disease. 49:1878-82.

Taylor AR, Barr JW, Hokamp JA, Johnson MC, Young BD. 2012. Cytologic diagnosis of disseminated histoplasmosis in the wall of the urinary bladder of a cat. Journal of the American Animal Hospital Association. 48(3):203-8.

Toranzo Al, Tiraboschi IN, Fernández N, Ibarra-Camou B, Rivas MC, Lee W, Davel G, Canteros CE. 2009. Diagnóstico molecular de histoplasmosis humana en muestras de sangre entera. Revista Argentina de Microbiología. 41:20-6.

Vite-Garín T, Estrada-Bárcenas DA, Cifuentes J, Taylor ML. 2014. The importance of molecular analyses for understanding the genetic diversity of Histoplasma capsulatum: an overview. Revista Iberoamericana de Micología. 31(1). doi:10.1016/j.riam.2013.09.013

Wheat L. 2006. Histoplasmosis: a review for clinicians from non-endemic areas. Mycoses. 49(2006):274-82.

Wheat LJ, Conces D, Allen SD, Blue-Hnidy D, Loyd J. 2004. Pulmonary histoplasmosis syndromes: recognition, diagnosis, and management. Seminars in Respiratory and Critical Care Medicine. 25(2):129-44.

Wheat LJ, Kauffman CA. 2003. Histoplasmosis. Infectious Disease Clinics of North America. 17(1):1-19, vii.

Wheat LJ, Kohler RB, Tewari RP. 1986. Diagnosis of disseminated histoplasmosis by detection of Histoplasma capsulatum antigen in serum and urine specimens. The New England Journal of Medicine. 314(2):83-8.

Woods JP. 2003. Knocking on the right door and making a comfortable home: Histoplasma capsulatum intracellular pathogenesis. Current Opinion in Microbiology. 6(4):327-31. 